\title{
WINE AND WINE TOURISM IN MACEDONIA
}

\author{
Assoc. Prof. Cane Koteski, PhD \\ University “Goce Delcev”, Faculty of Tourism and Business Logistics, „Krste Misirkov“ 10-A, 2000 \\ Stip, Makedonija, cane.koteski@ugd.edu.mk \\ Assoc. Prof. Zlatko Jakovlev, PhD \\ University “Goce Delcev”, Faculty of Tourism and Business Logistics, „Krste Misirkov“ 10-A, 2000 \\ Stip, Makedonija, zlatko.jakovlev@ugd.edu.mk \\ Dragana Soltirovska, master \\ „Franc Rozman“ 106, 1300 Kumanovo, Makedonija, dragana.ej@gmail.com
}

Professional Paper

doi:10.5937/jouproman4-11128

\begin{abstract}
Wine (Latin: vinum) is an alcoholic beverage obtained by the fermentation of the grapes, the fruit of the vine plant. In Europe, according to legal regulations, the wine is the product obtained exclusively by full or partial fermentation of fresh grapes, clove or not, or of grape must. The transformation of grapes into wine is called vinification. The science of wine is called oenology. In some other parts of the world, the word wine can be true of alcohol obtained from other types of fruit. These wines are referred to as fruit wines, or wear a name by which the fruit is used for obtaining them (for example apple wine). Wine tourism is a type of tourism that involves visiting wineries, tasting, consumption and purchase of wine, usually directly from the manufacturer. This type of tourism includes visits to wineries, vineyards and restaurants famous for special local wines, as well as organized wine tours, visits to wine festivals and other special events. Many wine regions around the world to promote this tourism because it affects very positively to the local economy. In these regions, viticulture and hospitality organizations have spent significant resources over the years for the promotion of wine tourism. Wine tourism in my country is respected, but strong growth.
\end{abstract}

Key words: wine, oenology, tourism, wineries, promote.

\section{Introduction}

The story of the Macedonian wine is a story with countless characters, tastes and secret recipes that traditionally for centuries from generation to generation. "It is a story that knows no beginning or end" - this is a statement of Macedonian winemakers who are very proud of their tradition of icing of vineyards from many different and unique varieties and manufacture of wines. Macedonian wine is one of the symbols of the country together with the sun, the food and the endless natural beauty. Under the old storytellers who will meet the plantations Vineyard biggest secret of taste of wines from Macedonia's sun to the region of Central Macedonia gives its specificity of each grape. When you start from Veles to Kavadarci, Negotino, Demir Kapija to Gevgelija you through vineyards and flooding large and small wineries that very authentic way with its architecture tell macedonian wine story. In Macedonia in the last ten years intensively developed and wine tourism with small wineries around the original atmosphere you back to the past and tradition of enjoying wine story. Of the capital Skopje until south of the country already are functioning real small oasis with wine houses, wineries and gorgeous several-offer for lovers of pleasure and tasting of wines and authentic Macedonian food. Who once seen Macedonia must remember the taste of the wines from this country and the irresistible charm of these areas. Some of Macedonian wineries working intensively in this direction. Wineries in its offer includes accommodation in their facilities to attract tourists who want to experience something different in this aspect. While staying in one of the apartments at one of the wineries, nearly every part of which is connected with the production of wine grape cultivation, packaging, sorting and the like, it is within your reach and you fully comprehend the process of creating a new wine. 
Some of Macedonian wineries have a rich and long history. At that point, you can really experience something different apart from the already routine vacation that includes beach and lake / sea.

\section{Macedonian wine}

Macedonia has a rich wine history. During the time of Philip II and Alexander the Great, the members of the Macedonian royal dynasty known as great lovers of wine. This tradition continued during the Roman Empire where Macedonia was one of the most important wine regions of the empire. Also significance of the wine is kept during the penetration of Christianity, when almost all Orthodox Church ceremonies conducted in churches wine is part of the tradition. Today Macedonia has 24,000 hectares of vineyards and annually Macedonian wineries produce about 236,000 tons of grapes, which is equal to 220 million liters, putting the country in 25 th place in the world. The official domestic consumption is more than 10 million gallons that only 5\% of Macedonian wine production is used for domestic consumption.

\subsection{Classification of wine}

Wine in many ways is a complex brew. The method of its manufacture, combinations of different grape varieties, the richness of aromas and flavors that develop in the glass, the complexity of factors that influence the development of the characteristics of the wine ... and many other reasons make wine only liquor, while explaining and our fascination with it. The biggest division is:

- White wine - produced from white wine grape varieties

- Red wine - produced from red wine grape varieties

- Rose wine - produced from red wine grape varieties, but in the production process there is limited contact between the juice and skins of grape
We can list other types of wines: still and sparkling wine, dry wine, semi-dry, semi-sweet and sweet wines, table wines, wines strengthened etc.

\subsection{How to serve wine}

Proper temperature of serving wine will undoubtedly improve its taste and smell. Excessively chilled wine loses its aroma and taste and insufficiently cooled wine uncomfortable drinking, primarily due to excessive evaporation of the alcohol covers all odors and changing the characteristics of the wine.

- Red wine is served at a temperature of 16

${ }^{\circ} \mathrm{C}$ to $18^{\circ} \mathrm{C}$

- White wine is served at a temperature of $12^{\circ} \mathrm{C}$ to $14^{\circ} \mathrm{C}$

- Rose wine served at a temperature of $10^{\circ}$ $\mathrm{C}$ to $12^{\circ} \mathrm{C}$

- Sparkling wine is served at a temperature of $8^{\circ} \mathrm{C}$ to $10^{\circ} \mathrm{C}$

Serving of wine is made in wine glasses. There are basically 4 types of wine glasses, for the red, white, sparkling and dessert wine. Wine glass must be clean and thin glass without engravings. The bracket height is different and it is determined how much heat the wine over the hand. The glass must be of greater volume, so for example, if the glass Pour $150 \mathrm{ml}$ wine, its volume should be at least $300 \mathrm{ml}$.

\section{Wine tourism}

Wine tourism $=+$ wine industry + tourism. Wine tourism is a complex phenomenon: culturally authentic occasion for festivals dedicated to wine affects the architecture of the village, educational, romantic.

- "Wine tourism is visiting vineyard, wineries, wine festivals and exhibitions are organized in order for recreation" (Johanson, 1997). 
- Wine tourism - "Visiting vineyard, wineries, wine festivals, wine exhibitions in the wine tasting and / or sightseeing, wine regions are the primary motives" (Hall et al, 2000).

Wine Tour includes: food and wine, enjoying the environment, living or extended recreation, many cultural, natural and other activities that are available in the wine regions. Economic and social benefits of wine tourism, an increased number of visitors (domestic and foreign) coming several times, extended holidays and increased spending of visitors increased satisfaction among visitors due to increased entrepreneurship to tourists, increased demand for sales of wine "from the basement".

\subsection{Wine tourists}

Wine tourists are visiting the vineyard, wineries, wine festivals and wine shops in order to rest. Wine tourists can be divided into three categories according to incentive / pending:

- Random or curious wine tourists

- Interested wine tourists

- Committed wine tourists

Motivation wine consumer may be: wine tasting, learn something new about wine, to be in a rural environment, to enjoy the beauty of vineyard, learn about culinary tourism, have fun, appreciate and architecture and to know eco tourism etc.

Services in wine tourism: tourists expect full sensory experience, new knowledge for a particular region, and an opportunity for relaxation; attention to accommodation, restaurants, hospitality, value, quality, attraction and many activities and information available; recommendations from the owners of wineries.

\subsection{Wine regions in Macedonia}

According to climate characteristics and EU classification, Republic of Macedonia is considered as III-C-b area for growing vines and adopted oenological rules governing this area. The main feature of this area is that guilt can have acidification, but not to enrich, which corresponds to the law and current practice of winemaking in the country.

In Macedonia there is a wine-growing area, which geographically can be divided into three regions:

- Vardar valley, is Central Region (Povardarie viticultural area) covers about $83 \%$ of total production,

- West (Pelagonia-Polog region) covers $13 \%$ of production and

- Eastern Region (former PcinjaOsogovo viticultural area) - includes $4 \%$ of total production.

The three regions are divided into 16 sub-regions (vineyards) are characterized with different production conditions and different intensity of production. The largest production of wine grapes and wine takes place in the Tikves region. Tikves covers all areas suitable for cultivation of wine grapes in Kavadarci, Negotino and Demir gate, as well as parts of Prilep and Veles. The climatic conditions in the region allow successful cultivation of wine grape varieties in all stages of ripening of the grapes. The main varieties grown in the region are red Vranac, Merlot, Cabernet Sauvignon, Pinot Noir, Kadarka, white Chardonnay, Belan, Muscat, Riesling, Sauvignon Blanc, Semilon, Smederevka, Rkaceteli, Muscat Ottonel, Temjanika, Zilavka and rosé Stanushina.

\section{Wineries in Macedonia}

The proud Macedonians for centuries used the extremely fertile soil and favorable climatic conditions for the cultivation of high quality red and white grape varieties. 
Fresh and harmonious white grape varieties and fruity aroma of red wines due to different altitudes where they are vineyard. Environmental clean environment provides an opportunity Macedonian Ecological grape sprayed only 4 times in year. Macedonia has about 50 wineries, but I will write for one of them.

\subsection{Popova Kula winery}

Popova Kula winery, located near the Kapija canyon is the winery which changed the concept of wine tourism in the country and has managed to merge wine and wine tourism in a project unique to Macedonia. The winery itself is a greenfield investment and invention of Jordan Trajkov, the current director and founder. Popova Kula is situated in a beautiful building that consists of a modern winery, hotel, tasting rooms, restaurant, gift shop and more recently, and a conference room. Construction began in 2004, and in August 2005 was the first harvest, and has since started to make their wine. In early 2009 the construction was over, when they are open and the hotel and restaurant. The capacity of the winery is 650,000 liters, but current production is between 100,000 and 150,000 liters. The wines are made from grapes obtained partly from their own vineyards surrounding the winery. Popova Kula owns 9 ha with "old" vineyards and 14 hectares of newly-bought and planted vineyards. Stanushina a variety grape is indigenous to Macedonia, and this winery is "responsible" for promoting the forgotten wine variety, as a sign of recognition of the winery. About two-thirds of their production going for export. The main destinations are: Belgium, Bosnia, Czech Republic, Germany, Netherlands, Poland, Serbia, Switzerland, and Hong Kong, the US and Australia. Popova Kula winery has five lines of wines: Classic, Demir Kapija, Reserve, Stanushina and Perfect Choice.

\section{Conclusion}

Wine in Macedonia has a long tradition and history. For foreign tourists to be aware, that Macedonia can taste quality wines it requires promotional material that will highlight the features of the Macedonian wine and at the same moment and beauties of Macedonia as a tourist destination. All wineries are investing in all aspects of the marketing mix and together with the Government of Macedonia are trying to promote Macedonian wine. Macedonia is a country with great potential for development of this tourism. Some of Macedonian wineries have a rich and long history. At that point, you can really experience something different apart from the already routine vacation that includes beach and lake / sea. Based on the fact that we have the ideal climate and soil conditions, vineyards in excellent condition that produce high quality grapes and have investments and private initiative we believe that Macedonian wine will become recognized and demanded by consumers of wine worldwide. I invite you to try Macedonian wine and a wine tour around the country. I am sure that you will be amazed.

\section{References}

Jakovlev, Z., Angelkova, T., "Leisure and alternative tourism", UGD Stip FTBL Gevgelija (2011)

Koteski, C., "A Survey of the tourism market, authorized lectures for internal use", Stip-Gevgelija (2011)

Jakovlev, Z., "Animation in tourism", UGD Stip FTBL Gevgelija (2011)

Phillimore, J., Goodson, L., Qualitative research in tourism, Routledge (2004)

www.popovakula.com

$\underline{\text { www.vino.mk }}$ 